\title{
PHILOSOPHICAL THOUGHT OF LIBRARY SCIENCE ACCORDING TO RANGANATHAN'S VIEWPOINT: A BRIEF STUDY
}

\author{
Sudeshna Karmakar \\ sudeshnakarmakar15@gmail.com \\ Librarian, Kendriya Vidyalaya, Boudh, Odisha (India)
}

Abstract-Shiyali Ramamrita Ranganathan introduced a number of classical theories and their practical applications with laws, rules and regulations. In this paper, I mainly applied the philosophical oath of Hippocrates and the philosophical thought of Plato in Library Science for the betterment of library and information centres more user-friendly, user-oriented and also more practical.

Keywords-Bentham, Hippocrates, Library science, Philosophy, Plato.

\section{INTRODUCTION}

S.R. Ranganathan is known to the world for his contributions and advancement of the discipline of library science and librarianship as a profession. Ranganathan laid the foundation of library science as a discipline in India through the laws, theories, principles and canons. The main influencing factors behind the philosophy of library science stated by Ranganathan are fully depends on the famous philosophers namely- Plato, Hippocrates. Ranganathan's five laws of library science propounded succinctly each in four to six words only, is the epitome of the operational philosophy of librarianship. This is because five laws are based on solid philosophical foundation based on theory of the famous philosophers.

\section{LITERATURE REVIEW}

Ray (2015) study revealed that Indian classical epic literature and the Laws of Manu known as Manu-Samhita or Manu-Smiriti had a great impact in the Ranganathan's philosophical thought of librarianship.

\section{OBJECTIVES OF THE STUDY}

$>$ To find out the real philosophical thought in the library science.

$>$ To know about philosopher's idea that is taken by Ranganathan in his philosophy of library science.

\section{WHAT IS PHILOSOPHY?}

Philosophy is basically the study of general and fundamental problems concerning matters such as existence, knowledge, values, reason, mind and language.

\section{WHAT IS LIBRARY SCIENCE?}

Library Science is basically the study of multidisciplinary field that applies the practices, perspectives, and the tools of management and education.

\section{FIVE LAWS OF LIBRARY SCIENCE}

$>$ Books are for use

$>$ Every reader his/her book

$>$ Every book its reader

$>$ Save the time of the reader

$>$ Library is a growing organism

\section{PLATO'S PHILOSOPHICAL THOUGHT}

Plato stated that the world is constantly undergoing change. The seasons reflect change. Nothing is ever permanent in the world. Even the present is deceiving. The concept of Plato should be used by Ranganathan in his philosophical thought. He stated in his fifth law that the library is a living institutional organisation which is constantly to be changed according to time. So that the library not to be growing as a static entity but as a dynamic entity. For the reason the growth of a library not withheld due to lack of forethought and planning.

\section{HIPPOCRATES OATH AND LIBRARY SCIENCE}

By applying the Oath of Hippocrates we modernized the vision of the library in such a way like-Treat every user as a patient, who is seeking medication for the treatment of his disease which may be stated literally as his needs to DOI Number: https://doi.org/10.30780/IJTRS.V04.I07.003

pg. 21 


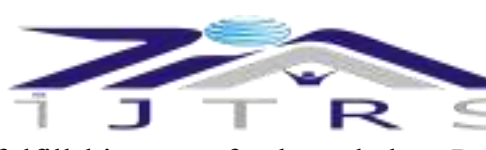

International Journal of Technical Research \& Science

fulfill his quest for knowledge. Ranganathan applied this philosophy in his second law of library science "Every reader his/her books". This law stands for the mandatory provision of library service to each/every users according to their needs. Every reader of a library should have the books which he wants. It always advocates the universalization and democratization of library service. In the early times only a privileged classes belonging to the higher class or upper class of the society were given access to the libraries and books. But in the recent times every reader is valuable like every patient in medical science. Hippocrates was the first person who changed the concept of medical science in the such a way like- He stated that diseases were caused naturally not by any superstition and gods in the same way Ranganathan change the philosophy of library like- library is not a place for privileged persons he stated library is for all citizens that he stated in his second and third law of library science.

\section{SIMILARITY BETWEEN TWO CONCEPTS OF MEDICAL SCIENCE AND LIBRARY SCIENCE}

Ranganathan in his Five Laws gave special emphasis on the word 'every' that means equal rights for every citizen. Because libraries collect books for use, store books for use and also provide services for use. For maximum use of library service the role, responsibility of librarian is most important. Librarian played a role of guide and philosophers for the users. In the same way in the medical science profession the doctors are responsible for patient like their guide and philosophers. 10. Professional code of Ethics in Librarianship and Hippocrates Oath: Other aspect of Hippocrates Oath which strengthens its position as a model code of professional ethics is the inclusion of guidance for entering the profession. Medical practitioners have an obligation to teach his/her family the art of medicine, if they want to learn it, without tuition or any condition of service. In this way, it shapes the medical community of inclusive. At the same time, the Oath sets up medical knowledge not as a knowledge which is good in itself, but as a knowledge that generates obligations in those who possess it. In the same manner the code of professional ethics for librarians describes that - The goal of librarianship is to mediate between humanity and humanity's store of recorded knowledge and information; to encourage an informed, enlightened and empowered citizenry; and to join with others in the 'fight for intellectual freedom and access to information'. To build up this image for the library and information science profession, and to establish quality, a set of ethical codes has to be formulated and is to be practiced by librarians and information professionals. The main characteristics/attributes are same in medical as well as library and information science profession. These are: a. Extensive period of training. $b$. Expertise. c. Service orientation. d. Self motivation. e. Autonomy. Medical Science and Library Science the Ultimate aim of the two disciplines: Serve the Community in a better way.

\section{PROFESSIONAL CODE OF ETHICS IN LIBRARIANSHIP AND HIPPOCRATES OATH}

Other aspect of Hippocrates Oath which strengthens its position as a model code of professional ethics is the inclusion of guidance for entering the profession. Medical practitioners have an obligation to teach his/her family the art of medicine, if they want to learn it, without tuition or any condition of service. In this way, it shapes the medical community of inclusive. At the same time, the Oath sets up medical knowledge not as a knowledge which is good in itself, but as a knowledge that generates obligations in those who possess it. In the same manner the code of professional ethics for librarians describes that - The goal of librarianship is to mediate between humanity and humanity's store of recorded knowledge and information; to encourage an informed, enlightened and empowered citizenry; and to join with others in the 'fight for intellectual freedom and access to information'. To build up this image for the library and information science profession, and to establish quality, a set of ethical codes has to be formulated and is to be practiced by librarians and information professionals. The main characteristics/attributes are same in medical as well as library and information science profession. These are:

$>$ Extensive period of training
$>$ Expertise
$>$ Service Orientation
$>$ Self-Motivation
Autonomy

\section{LAISSEY-FAIRE}

Bentham stated that 'Laissey-faire' is the economic theory of early liberalism based on the doctrine- "that government is best which governs least". The libraries public libraries in general and academic libraries in particular should adopt a socialistic approach towards society kicking away their Lessiey-faire approach.

\section{CONCLUSION}

All subjects end with the philosophy so in the same way Library and Information Science is also ends with the philosophy. The Medical Science and Library Science the ultimate aim of both disciplines is to serve the community DOI Number: https://doi.org/10.30780/IJTRS.V04.I07.003

pg. 22

$$
\begin{aligned}
& \text { www.ijtrs.com } \\
& \text { www.ijtrs.org }
\end{aligned}
$$


in a better way and fulfill the needs of every individual who comes under the services of both.

\section{REFERENCES}

[1] Partha Pratim, "Influence of Manu on Ranganathan's philosophy of library science : An overview", Annals of Library and Information Studies, 62, pp 213-216, 2015. Retrieved December 26, 2017, from http://hdl.handle.net/123456789/33713.

[2] (n.d.). Retrieved December 28, 2017, from http://en.m.wikipedia.org/wiki/Hippocratic_Oath. 